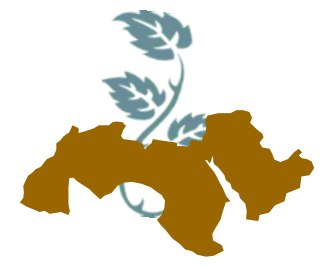

Arab Univ.

J. Agric. Sci., Ain Shams Univ., Cairo Special Issue, 26(2A), 1165-1173, 2018

\title{
INFLUENCE OF NUTRITIONAL AND CLIMATIC CONDITIONS ON MYCELIAL GROWTH OF THREE OYSTER MUSHROOM STRAINS
}

\author{
Norhan H. Abdel Aziz'; Nahed, S. Yousef ${ }^{2}$; M.E. El-Haddad ${ }^{3}$ \\ and T.S. El-Tayeb ${ }^{3}$ \\ 1- Central Lab. for Agric. Climate, Agric. Res. Center (ARC), Giza, Egypt \\ 2- Food Sci. and Tech. Dept., Fac. of Home Economic, Al-Azhar Univ., Tanta, Egypt \\ 3- Agric. Microbiology Dept., Fac. of Agric., Ain Shams Univ., Cairo, Egypt
}

Keywords: Oyster mushroom, optimal conditions, nutrient media, mycelial growth rate.

\section{ABSTRACT}

The mycelial growth rate of three oyster mushroom strains namely Pleurotus erengii, $P$. ostreatus and $P$. florida was examined on six different agar media (malt extract, Potato dextrose, rose bengal, corn meal, czapek's dox and waksman's glucose agar media) to select the most suitable one. Effect of $\mathrm{pH}$ was also examined at different values (5.0, $5.5,6.0,6.5$ and 7.0) on the selected medium. Results indicated that Malt extract agar medium was the most suitable one for mycelium growth of all the tested mushroom strains, being the highest (9 $\mathrm{cm}$ ) for $P$. erengii and $P$. ostreatus at $\mathrm{pH} 7$ and 9 $\mathrm{cm}$ at $\mathrm{pH} 6-6.5$ for $P$. florida after 6 days of incubation. The mycelia growth of the tested oyster mushroom strains was also examined at different temperatures $\left(15,20,25,30\right.$ and $\left.35^{\circ} \mathrm{C}\right)$ and different levels of relative humidity $(50,65,75,85,95$ and $100 \%)$ on malt extract agar medium. The highest mycelial growth rate was obtained at $25^{\circ} \mathrm{C}$ and relative humidity of $65 \%$ after 6 days of incubation for the three tested oyster mushrooms.

\section{INTRODUCTION}

Mushroom is one of the man's earliest food which have come to be recognized as highly nutritive food, low in calories, rich in protein and certain vitamins. A distinctive feature of mushroom protein is that it comprises of all the essential amino acids and has highly digestible value. Its nutritional value can be compared to those of eggs, milk, and meat (Oei, 2003). The vitamins of mushrooms are not destroyed by cooking, drying and freezing. Mushroom has been used as a food and in medicine by different civilizations since immemorial time, due to its delicious taste and dietetic qualities. Mushroom has also beneficial qualities, like lowering the blood cholesterol level, warding against cancer and invigorating hair growth. Morais et al (2000) and Sánchez (2004) reported that the fresh mushroom contains about $85-90 \%$ moisture, $3 \%$ protein, $4 \%$ carbohydrates, $0.3-0.4 \%$ fats and $1 \%$ minerals and vitamins. The total energetic value of mushroom caps is between 250 and $350 \mathrm{cal} / \mathrm{kg}$ of fresh mushrooms weight (Oliver and Delmas, 1987; Laborde, 1995). The production of mushrooms is regarded as the second most important Commercial microbial technology next to yeast (Pathak et al 2009). Oyster mushroom (Pleurotus spp.) cultivation has increased tremendously throughout the world during the last few decades (Royse, 2002). These mushrooms accounted for $14.2 \%$ of the total world production of edible mushrooms in 1997 (Chang, 1999). Although commonly grown on pasteurized straw of wheat or rice, they could be also cultivated on a wide variety of substrates that contain lignin and cellulose. Oyster mushrooms cultivation can play an important role in managing organic wastes which have become problematic for disposal. Oyster mushrooms can grow at moderate temperatures ranging from 20 to $30^{\circ} \mathrm{C}$ and humidity ranging from 55 to $80 \%$ for a period of 6 to 8 months in a year. It could also be cultivated in summer season, by providing the extra humidity for its growth. Hilly areas (above $900 \mathrm{~m}$ ) are also suit- 
able for its growth. Three primary factors can affect the yield of oyster mushrooms, i.e. temperature, compost component and humidity. The process of cultivating oyster mushrooms has 3 main steps: isolating mushroom from fruiting bodies, preparing primary and secondary spawn and cultivating mushrooms from these spawns to harvest fruiting bodies (Dung, 2003).

The objectives of this study are to determine the best nutritive medium, the optimal $\mathrm{pH}$ value, relative humidity and temperature for the in vitro cultivation of each of the three tested mushroom strains.

\section{MATERIALS AND METHODS}

\section{Tested strains}

The pure cultures of $P$. erengii , $P$. ostreatus and $P$. florida are a part of Mushroom Laboratory Culture Collection (MLCC), allocated at Mushroom Production and Research Unit,Central Laboratory for Agricultural Climate, Agricultural Research Center (ARC). Their numbers in this collection are 555,21 , and 14 in respective order. These cultures were kindly provided from Germany, SomycelFrance and STCPL-Hong Kong respectively.

\section{Media used}

The following media were tested to find out the best one, giving the highest linear growth rate of the examined mushroom strains. Their components are expressed as $(\mathrm{g} / \mathrm{l})$ : Waksman,s glucose agar (WGA) medium
(Waksman, 1922)

Glucose 10.0, peptone5.0, beef extract 5.0, distilled water up to $1000 \mathrm{ml}$, agar12.5 and. $\mathrm{pH} 7.0$.

Malt extract agar(MEA) medium (Gutz and Doe, 1973)

Malt extract 30.0, peptone5.0, distilled water up to $1000 \mathrm{ml}$, agar 15.0 and $\mathrm{pH} 5.4$.

Corn meal agar (CMA) medium, quarter strength (ATCC-2221) (Hazen and Reed, 1955)

Corn meal infusion $250.0 \mathrm{ml}$, distilled deionized water up to $1000 \mathrm{ml}$, agar15.0 and $\mathrm{pH} 5.6$
Potato dextrose agar(PDA) medium (Ahmed, 2001)

Potato extract $200.0 \mathrm{ml}$, dextrose 20.0, distilled water up to $1000 \mathrm{ml}$, agar 15.0 and $\mathrm{pH} 5.6$

Rose bengal agar (RBA) medium (Smith and Dawson, 1944)

Peptone 5.0, dextrose 10.0, $\mathrm{KH}_{2} \mathrm{PO}_{4}$ 1.0, $\mathrm{MgSO}_{4} .7 \mathrm{H}_{2} \mathrm{O} 0.50$, Rose bengal 0.05, Chloramphenicol. 0.10 , distilled water up to $1000 \mathrm{ml}$, agar 15.0 and $\mathrm{pH} 7.2$.

Czapek's dox agar(CDA) medium (Prauser and Folta, 1968)

Sucrose 20.0, $\mathrm{NaNo}_{3}$ 2.0, $\mathrm{KH}_{2} \mathrm{PO}_{4}$ 1.0, $\mathrm{MgSO}_{4} .7 \mathrm{H}_{2} \mathrm{O} \quad 0.50, \mathrm{KCL} 0.50, \mathrm{Fe}_{2} \mathrm{SO}_{4}$ 0.01, distilled water up to $1000 \mathrm{ml}$, agar 15.0 and $\mathrm{pH}$ 7.0.

Effect of different nutrient media on the growth of the tested mushroom strains

The aforementioned media were tested to select the most suitable one, giving the highest mycelial growth rate of the tested mushroom strains. The media were adjusted to their sutible $\mathrm{pH}$ before autoclaving. Media were sterilized by autoclaving at $121^{\circ} \mathrm{C}$, for 20 minutes, $15 \sim 20 \mathrm{ml}$ of each medium was aseptically poured into plates. A $0.5 \mathrm{~cm}$ diameter plug of an inoculum was picked up with sterilized cork borer from 7days old culture, grown on potato dextrose agar medium and placed in the center of each plate of the tested six media and incubated for 6 days at $25^{\circ} \mathrm{C}$. The mycelia radial growth was measured after 2,4 and 6 days of incubation.

Effect of different pH levels on the growth of the tested mushroom strains

A $0.5 \mathrm{~cm}$ diameter plug of an inoculum was picked up with sterilized cork borer from 7 days old culture, grown on the selected medium and placed in the center of each plate The medium was adjusted to different levels of $\mathrm{pH}(5,5.5,6,6.5$ and 7$)$ with the addition of $1 \mathrm{NNaOH}$ or $1 \mathrm{NHCl}$ before autoclaving at $121^{\circ} \mathrm{C}$ for 20 minutes. Three replicates of each treatment were prepared. Plates were incubated for 6 days at $25^{\circ} \mathrm{C}$. The mycelial radial growth was measured after 2,4 and 6 days of incubation. 

of Three Oyster Mushroom Strains

\section{Effect of different temperatures on the growth of the tested mushroom strains}

The effect of different temperatures, i.e. 15, 20 , 25,30 and $35^{\circ} \mathrm{C}$ on the mycelium linear growth $(\mathrm{cm})$ of the tested strains were determined on the selected medium. For each treatment, three replicates were inoculated with $0.5 \mathrm{~cm}$ agar discs taken from actively growing cultures with sterilized cork borer. The mycelial radial growth was measured after 6 days of incubation.

Evaluation of different relative humidity( $\mathrm{RH})$ levels on radial growth of tested Pleurotus strains

After optimization of temperature, Pleurotus species were optimized for their $\mathrm{RH}$. Therefore, different levels of $\mathrm{RH}(50,65,75,85,95$ and 100 $\%)$ of the selected medium were adjusted according to Solomon (1951) by taking accurate weight of either $\mathrm{NaCl}$ or $\mathrm{KOH}$, and then dissolved in 100 $\mathrm{ml}$ deionized distilled water to obtain the required levels of $\mathrm{RH}$. Petri-dishes (9 $\mathrm{cm}$-diameter) containing $15 \sim 20 \mathrm{ml}$ of the selected medium were inoculated with agar discs $(0.5 \mathrm{~cm})$, taken from actively growing cultures with sterilized cork borer, then the plates were converted. Ten $\mathrm{ml}$ of each prepared solution were placed in the cover of each Petri dish, then sealed with para film and incubated at $25^{\circ} \mathrm{C}$ for 6 days. The diameter of the mycelium extension was measured every 2 days with the help of a ruler until completion of growth in any plate. Diameter of mycelial growth was measured as described by Imtiaj et al (2009).

Average mycelial growth was calculated as follows:

$1^{\text {st }}$ Petri dish $(\mathrm{AB} 1+\mathrm{CD} 1+\mathrm{EF} 1) / 3=\mathrm{R} 1$

$2^{\text {nd }}$ Petri dish $(A B 2+C D 2+E F 2) / 3=R 2$

$3^{\text {rd }}$ Petri dish $(A B 3+C D 3+E F 3) / 3=R 3$

Note: $A B, C D$ and $E F$ referrers to different three measures $(\mathrm{cm})$ for each plate (three replicates, $\mathrm{R} 1$, R2 \& R3 for each treatment).

Average mycelial growth of each strain is (R1+ $\mathrm{R} 2+\mathrm{R} 3) / 3$

\section{Statistical analysis}

The obtained results were statistically analyzed by using Statistical Analysis System (SAS, 2006). Least Significant Difference (LSD) test was used to test significance between means according to Snedecor and Cochran (1991).

\section{RESULTS AND DISCUSSION}

Oyster mushroom requires different nutrients and certain environmental conditions in order to grow and reproduce (Ravimannan et al 2014). Effect of different media on mycelial growth of the tested mushroom strains ( $P$.erengii, $P$. ostreatus and $P$. florida) are presented in Table (1). There are significant differences between radial growth in all tested media during the incubation period. The maximum linear growth rates for $P$. ostreatus, P.erengii and $P$. florida were recorded on malt extract agar medium being $8.1,7.39$ and $7.39 \mathrm{cmin}$ respective order after 6 days of incubation followed in general by PDA and RBA $(7.5 \mathrm{~cm})$. The CDA medium had the lowest radial growth rate as compared to the other tested media after 6 days of incubation. Radial growth of P.erengii and P. florida recorded $5 \mathrm{~cm}$ in CDA medium. In general, CDA medium gave lower values of radial growth for tested mushroom strains after 6 days of incubation (Shim et al 2003). Such differences in mycelial growth detected on the tested agar media may be due to the availability of different carbon sources and other required nutrients. Mycelium growth was marginally better on a medium containing glucose and sucrose than other carbon sources (Santiago, 1983). These results are in agreement with the findings of Hoa and Wang (2015), who reported that Pleurotus spp. showed faster growth of mycelium on malt extract and potato dextrose agar media, compared to the other tested media.

Results presented in Table (2). showed the effect of different $\mathrm{pH}$ levels on radial growth of $P$. erengii, $P$. ostreatus and $P$. florida growing on malt extract agar medium. The maximum linear growth rate $(9 \mathrm{~cm})$ was found at $\mathrm{pH} 7$ for $P$. erengii and $P$. ostreatus after 6 days of incubation, and $\mathrm{pH}$ 6-6.5 $(9 \mathrm{~cm})$ for $P$. florida. Low radial growth was observed at $\mathrm{pH} 6(6.83$ and $6.90 \mathrm{~cm})$ for $P$. erengii and $P$. ostreatus respectively and the lowest radial growth of $P$. florida $(7.5 \mathrm{~cm})$ was recorded at $\mathrm{pH} 5$.

$\mathrm{pH}$ is considered one of the prime factor that affects the growth of fungi. Karacanci (1997) and Sardar et al (2015) noticed that maximum mycelial

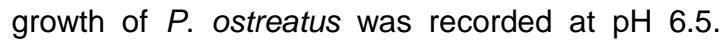
These results are in accordance with the findings of Suharban and Nair (1994), who reported that Pleurotus spp. grow faster on slightly acidic medium than basic one. 
Table 1. Effect of different nutrient media on liner growth rate of mushroom strains $P$. erengii, $P$. ostreatus and $P$. florida at $25^{\circ} \mathrm{C}$

\begin{tabular}{|c|c|c|c|c|}
\hline \multirow{3}{*}{ Tested agar media } & \multirow{3}{*}{ Interval (days) } & \multirow{2}{*}{\multicolumn{3}{|c|}{$\begin{array}{l}\text { Linear growth rate }(\mathrm{cm}) \\
\text { Tested mushroom strains }\end{array}$}} \\
\hline & & & & \\
\hline & & P. erengii & P. ostreatus & P. florida \\
\hline \multirow{3}{*}{ PDA } & 2 & 1.81 & 3.20 & 1.71 \\
\hline & 4 & 3.10 & 5.40 & 2.90 \\
\hline & 6 & 7.50 & 7.30 & 5.50 \\
\hline \multirow{3}{*}{ MEA } & 2 & 2.53 & 2.75 & 2.90 \\
\hline & 4 & 6.66 & 6.50 & 6.40 \\
\hline & 6 & 7.93 & 8.10 & 7.93 \\
\hline \multirow{3}{*}{ CDA } & 2 & 1.13 & 2.00 & 1.10 \\
\hline & 4 & 3.30 & 2.80 & 3.30 \\
\hline & 6 & 5.00 & 5.60 & 5.00 \\
\hline \multirow{3}{*}{ CMA } & 2 & 1.60 & 2.30 & 1.70 \\
\hline & 4 & 4.75 & 5.60 & 4.75 \\
\hline & 6 & 6.30 & 6.80 & 6.30 \\
\hline \multirow{3}{*}{ WGA } & 2 & 1.58 & 2.30 & 1.60 \\
\hline & 4 & 4.81 & 5.40 & 4.81 \\
\hline & 6 & 6.30 & 6.80 & 6.30 \\
\hline \multirow{3}{*}{ RBA } & 2 & 2.68 & 3.00 & 2.50 \\
\hline & 4 & 5.80 & 5.90 & 5.80 \\
\hline & 6 & 6.90 & 7.20 & 7.50 \\
\hline \multicolumn{2}{|c|}{ LSD } & 0.53 & 0.75 & 0.50 \\
\hline
\end{tabular}

PDA $=$ Potato dextrose agar medium, MEA $=$ Malt extract agar medium, CDA $=$ Czapek sdox agar medium, $\mathrm{CMA}=$ Corn meal agar medium, WGA = Waks man glucose agar medium, RBA = Rose bengal agar medium

Table 2. Effect of different $\mathrm{pH}$ levels on liner growth rate of mushroom strains on MEA medium at $25^{\circ} \mathrm{C}$

\begin{tabular}{|c|c|c|c|c|c|c|}
\hline \multirow{2}{*}{$\begin{array}{c}\text { Tested mushroom } \\
\text { Strains }\end{array}$} & \multirow{2}{*}{$\begin{array}{l}\text { Interval } \\
\text { (days) }\end{array}$} & \multicolumn{5}{|c|}{$\begin{array}{c}\text { Linear growth rate / cm on MEA medium } \\
\text { pH levels }\end{array}$} \\
\hline & & 5 & 5.5 & 6 & 6.5 & 7 \\
\hline \multirow{3}{*}{ P. erengii } & 2 & 2.00 & 2.53 & 2.70 & 3.20 & 3.00 \\
\hline & 4 & 6.00 & 6.66 & 5.78 & 7.00 & 6.66 \\
\hline & 6 & 7.20 & 7.93 & 6.83 & 8.16 & 9.00 \\
\hline \multirow{3}{*}{ P. ostreatus } & 2 & 2.50 & 2.75 & 3.51 & 3.28 & 4.35 \\
\hline & 4 & 6.80 & 6.50 & 7.00 & 5.90 & 6.80 \\
\hline & 6 & 8.00 & 8.10 & 6.90 & 8.30 & 9.00 \\
\hline \multirow{3}{*}{ P. florida } & 2 & 2.80 & 2.90 & 3.11 & 2.50 & 2.90 \\
\hline & 4 & 6.00 & 6.40 & 7.80 & 7.00 & 6.50 \\
\hline & 6 & 7.50 & 7.90 & 9.00 & 9.00 & 8.10 \\
\hline \multicolumn{2}{|l|}{ LSD } & 0.56 & 0.64 & 0.90 & 0.55 & 0.40 \\
\hline
\end{tabular}



of Three Oyster Mushroom Strains

Accordingly, in the light of the aforementioned results it could be concluded that most of Pleurotus spp. showed superior growth at $\mathrm{pH} 6$ to 7 . This might be attributed to genetic differences found in different species of genus Pleurotus (Sardar et al 2015).

The growth of oyster mushroom (Pleurotus spp.) was decreased at $\mathrm{pH} 5$. Such decrease in growth may be due to reduction of its enzymatic activities. Likewise observation has also been previously reported by Zadrazil (1978), who mentioned that $P$. ostreatus and $P$. erengii showed significant decreases in their mycelial growth at $\mathrm{pH}$ 4.0, which is too acidic. However, some Pleurotus spp. are characterized by wider growth adaptability scale for $\mathrm{pH}$ i.e. 5-8 as reported by Yadav (2001). The mycelial growth of $P$. ostreatus was better at $\mathrm{pH} 7.0$ as reported by Bugarski et al (2000).

Temperature is an important aspect in the selection of mushroom. The tropics, areas where high temperature remains most of the time, are not recommended for mushroom production. Tested oyster mushroom species exerted their highest growth rate at $25^{\circ} \mathrm{C}$, as shown in Fig. (1). Optimum temperature was reported within this range by Zharare et al (2010), who observed maximum growth of Pleurotus strains. Thus, it appears that 20-25C was universal temperature range for the mycelial growth of mushrooms. In addition, fungus also exhibited maximum enzymatic activity within this range and growth inhibition at elevated temperature was reported (Sardar et al 2015). Favorable temperature for growth was recorded at $25^{\circ} \mathrm{C}$ and the lowest growth has shown at 15 and $35^{\circ} \mathrm{C}$ Fig. (1). Shim et al (2003) reported that the mycelial growth of Paecilomyces fumosoroseus had been expedited gradually in proportion to the rise of temperature and the most suitable temperature was $25^{\circ} \mathrm{C}$. Similar results were obtained by Wei et al (2002), who reported a temperature range of 20 $31^{\circ} \mathrm{C}$ for the hyphal growth of $P$. flabellatus and concluded that a temperature of $25^{\circ} \mathrm{C}$ is the optimum. Similarly, Zharare et al (2010) found that $P$. sajor-caju can tolerate high temperature up to $35^{\circ} \mathrm{C}$. Temperature and $\mathrm{pH}$ affected the growth of Pleurotus spp. through suppressing their enzymatic activities in the cell (Sopit, 2006).
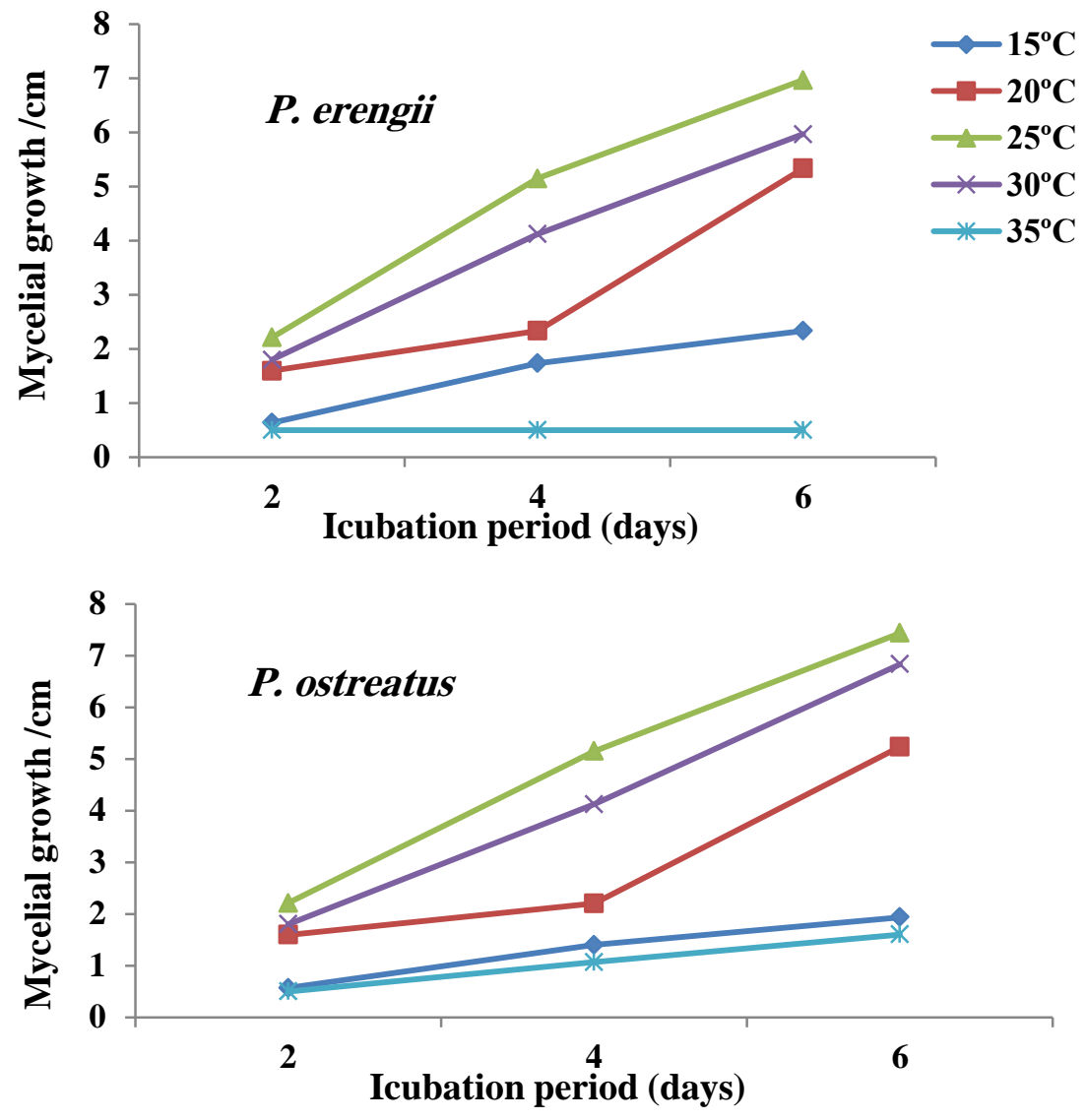

Arab Univ. J. Agric. Sci., Special Issue, 26(2A), 2018 


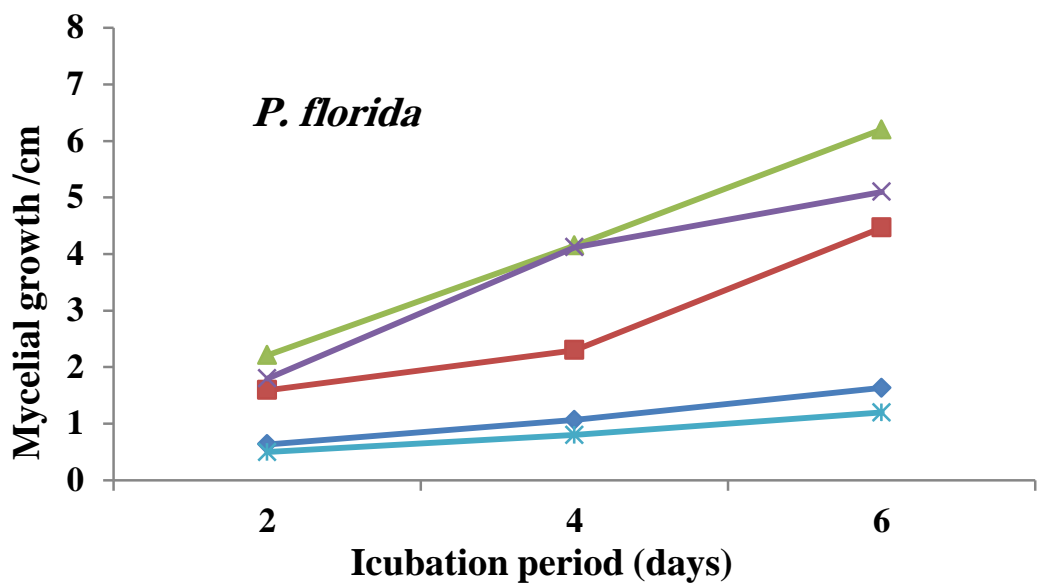

Fig. 1. Effect of different temperature on mycelial growth of $P$. erengii, $P$. ostreatus and $P$. florida.

The effect of relative humidity on radial growth of tested Pleurotus strains was studied under in vitro condition . Results are presented in Figure(2).There were significant differences in radial growth of Pleurotus strains at different levels of relative humidity. Maximum radial growth $(8 \mathrm{~cm})$ of the three tested Pleurotus strains was noticed at $65 \%$ relative humidity followed by $75 \%(6.9 \mathrm{~cm})$ while, it was significantly low at 95 and $100 \%$. Shukla (2003) observed maximum mycelial growth $(90 \mathrm{~mm})$ of Calocybe indica at 75 and $100 \%$ relative humidity while it was significantly low at 25 $\%(80 \mathrm{~mm})$ followed by $50 \%$ relative humidity (83.25 mm).

Accordingly, it could be concluded that, $P$. erengii, $P$. ostreatus and $P$. florida showed best growth when grown at temperature of $25^{\circ} \mathrm{C}$ and $65 \%$ relative humidity. As for among the different growing media, MEA medium proved to be the best one for the growth of Pleurotus spp. $\mathrm{pH}$ level must be maintained at 6-7 for best growth of oyster mushroom strains.

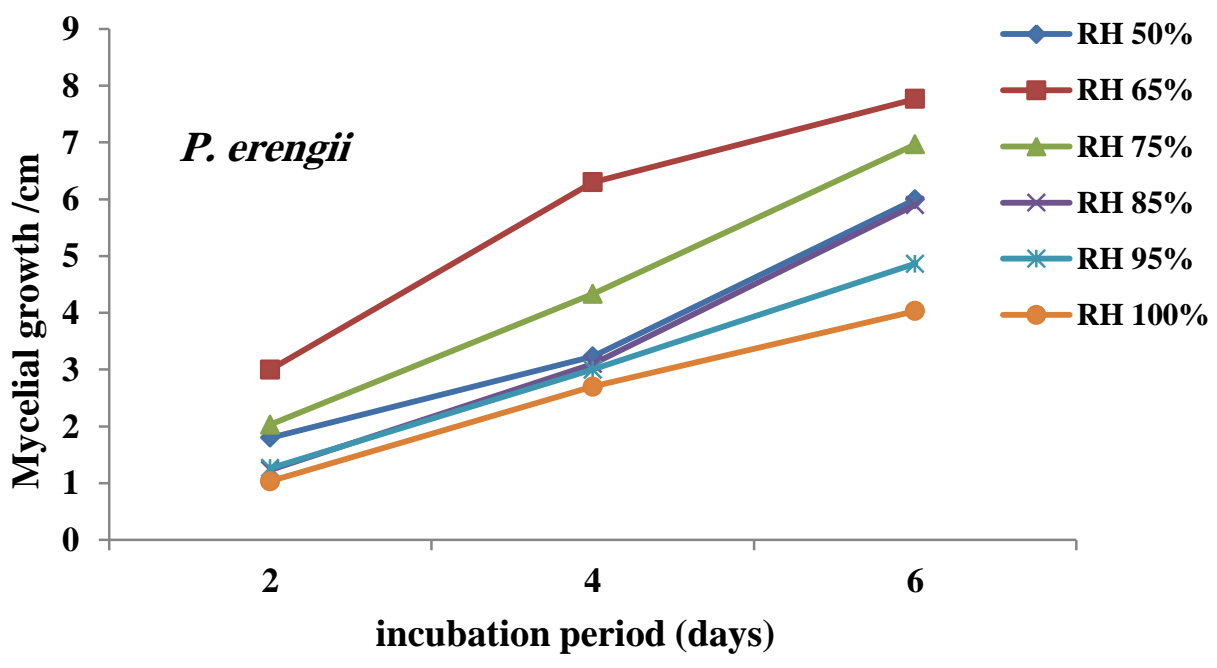

Arab Univ. J. Agric. Sci., Special Issue, 26(2A), 2018 

of Three Oyster Mushroom Strains
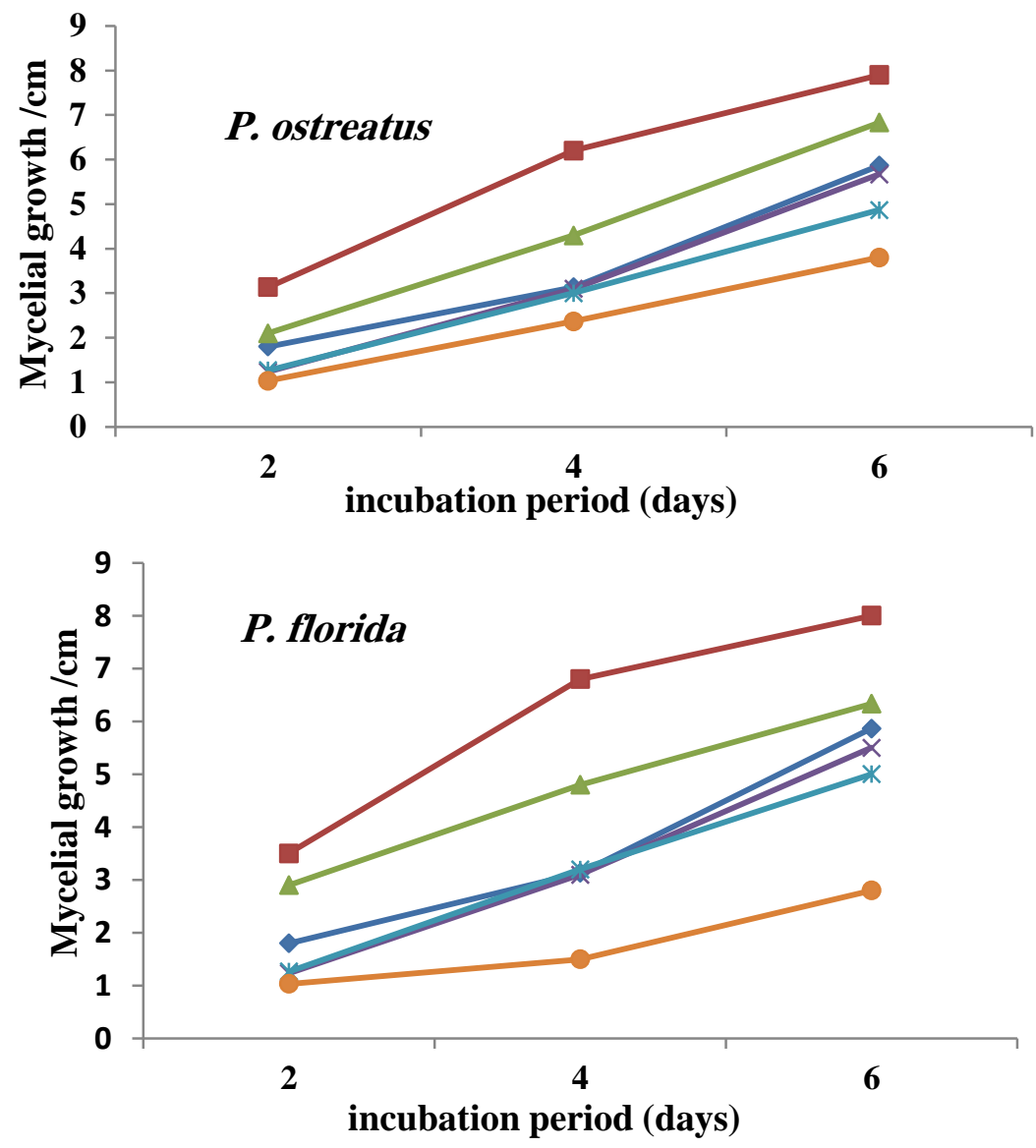

Fig. 2. Effect of different relative humidity $(\mathrm{RH})$ levels on mycelial growth of $P$. erengii, $P$. ostreatus and $P$. florida.

\section{REFERENCES}

Ahmed, M.A. 2001. Dictionary of the Fungal Terminology. Academic Book Shop. Egypt. pp. 230-231.

Bugarski, D., Gvozdenovic, D.J., Cervenski, J. and Takac, A. 2000. Effect of major environmental conditions on the development of the mycelium and growth of the oyster mushroom (Pleurotus ostreatus). In: II Balkan Symposium on Vegetables and Potatoes, 579, 319323.

Chang, S.T. 1999. World production of cultivated and medicinal mushrooms in 1997 with emphasis on Lentinus edodes. Int. J. Medici. Mush. 1, 291 - 300.

Dung, L.B. 2003. Mushrooms in Tay Nguyen (in Vietnamese). Ha Noi: Science and Technique. Cited from Sardar, H., Ali, M.A., Ayyub, C.M. and Ahmad, R. 2015. Effects of different cul- ture media, temperature and $\mathrm{pH}$ levels on the growth of wild and exotic Pleurotus species. Pak. J. Phytopathol., 27(2), 139-145.

Gutz, H. and Doe, F.J. 1973. Two different $\mathrm{h}^{-}$mating types in Schizosaccharomyces pombe. Genetics 74, 563-569.

Hazen, E.L. and Reed, F.C. 1955. Monograph Laboratory Identification of Pathogenic Fungi Simplified, American Lecture Series, Publ. No. 253, 100 p. Charles C. Thomas, Springfield, IL.

https: //Catalog.hardydiagnostics.com.

Hoa, H.T. and Wang, C.L. 2015. The effects of temperature and nutritional conditions on mycelium growth of two oyster mushrooms (Pleurotus ostreatus and Pleurotus cystidiosus). Mycobiol. 43(1), 14-23.

Imtiaj, A., Jayasinghe, C., Lee, G.W. and Lee, T.S. 2009. Comparative study of environmental and nutritional factors on the mycelial growth of 
edible mushrooms. J. Cult. Collect. 6(1), 97105.

Karacanci, S. 1997. An investigation on biomass production of Pleurotus sajor-caju and Lentinus edodes in submerged culture. Paper presented in Indian Mushroom Conference - 97 at NCMRT Solan from $10-13^{\text {th }}$ September, 7. Cited from Sardar, H., Ali, M.A., Ayyub, C.M. and Ahmad, R. 2015. Effects of different culture media, temperature and $\mathrm{pH}$ levels on the growth of wild and exotic Pleurotus species. Pak. J. Phytopathol., 27(2), 139-145.

Laborde, J. 1995. Dossier Pleurote. INRA, Centre de Recherches de Bordeaux, Station de Recherchessur les Champignons, Bordeaux, pp. 17-18

Morais, M.H., Ramos, A.C., Matos, N. and Santos-Oliveira, E.J. 2000. Production of shiitake mushroom (Lentinus edodes) on ligninocellulosic residues. Food Sci. Techol. Int., 6, 123128.

Oei, P. 2003. Mushroom Cultivation $3^{\text {rd }}$ ed. Appropriate technology for mushroom growers.Backhuys Publishers, Leiden. The Netherlands. 429 p.

Oliver, J.M. and Delmas, J. 1987.Vers la maîtrise des champignons comestibles. Biofutur 1, 2341.

Pathak, R., Joshi, N. and Dwivedi, R.R. 2009. Eco-friendly production of Agaricus bisporus (lange) imbach (white button mushroom). Nat. Sci., 6, 57-60.

Prauser, H. and Folta, R. 1968. Phagensensibilitat, Zellwandzusammensetzung and Taxonomie van actinomuceten. Z. Allg. Mikrobiol, 8, 39-64.

Ravimannan, N., Arulanantham, R., Pathmanathan, S. and Niranjan, K. 2014. Alternative culture media for fungal growth using different formulation of protein sources. Annals. Biol. Res. 5, 36-39.

Royse, D.J. 2002. Influence of spawn rate and commercial delayed release of nutrient levels on Pleurotus cornocopiae yield, size and time to production. Appl. Microbiol. Biotechnol. $17,191-200$.

Sánchez, C. 2004. Modern aspects of mushrooms culture technology. Appl. Microbiol. Biotechnol. 64, 756-762.

Santiago, C.M. Jr. 1983.Basidiocarp production in Volvariella volvacea in laboratory cultures. Kalikasan, Philippines Journal of Biology, 12, 70-76.
Sardar, H., Ali, M.A., Ayyub, C.M. and Ahmad, R. 2015. Effects of different culture media, temperature and $\mathrm{pH}$ levels on the growth of wild and exotic Pleurotus species. Pak. J. Phytopathol., 27(2), 139-145.

SAS 2006. Statistical Analysis System, SAS User's Guide Statistics. SAS Institute Inc., Editor, Cary, NC.

Shim, S.M., Lee, K.R., Kim, S.H., Im, K.H., Kim, J.W., Lee, U.Y., Shim, J.O., Lee, M.W. and Lee, T.S. 2003. The optimal culture conditions affecting the mycelial growth and fruiting body formation of Paecilomyces fumosoroseus. Mycobiol., 31(4), 214-220.

Shukla, C.S. 2003. Role of agronomical biochemical practices on growth and yield parameters of Calocybe indica, Ph.D. Thesis Submitted to IGKV, Raipur, 148 p.

Smith, N.R. and Dawson, V.T. 1944. The bacteriostatic action of rose bengal in media used for the plate counts of soil fungi. Soil Sci., 58, 467471.

Snedecor, G.W. and Cochran, W.G. 1991. Statical Method $7^{\text {th }}$ Ed. lowa State Univ. Press, Iowa, USA.

Solomon, M.E. 1951. Control of humidity with potassium hydroxide, sulphuricacid, or other solutions. Bul. Entomol. Res. 42, 543-554.

Sopit, V. 2006. Oyster mushroom cultivation on different cellulosic substrates. Res. J. Agri. Biol. Sci., 2(6), 548-551.

Suharban, M. and Nair, M.C. 1994. Physiological studies on Pleurotus spp. Mushroom Res. 3, 87-104.

Waksman,S.A. 1922. A method for counting the number of fungi in the soil. $\mathbf{J}$ Bacteriol 7(3), 339-341.

Wei, S.H., Jie,Y.Y., Rong, H.L., Li, H.L. and Yan, M.G. 2002. Effects of different cultivation conditions on hyphal growth of Pleurotus flabellatus. Edible Fungi of China. 23(2), 29-30.

Yadav, B.R. 2001. Physical and nutritional factors in relation to growth of Pleurotus sajor-caju(Fr.) Singer. J. Phytol. Res., 14, 95-98.

Zadrazil, F. 1978. Cultivation of Pleurotus. The biology and cultivation of edible mushrooms by S.T. Chang and W.A. Hayes (eds). Academic press INC. Orlando, Florida, 1(62), 521-558.

Zharare, G.E., Kabanda, S.M. and Poku, J.Z. 2010. Effects of temperature and hydrogen peroxide on mycelial growth of eight Pleurotus strains. Scientia Hortic., 125, 95-102. 